\title{
Paenibacillus koreensis sp. nov., a new species that produces an iturin-like antifungal compound
}

\author{
Young Ryun Chung, ${ }^{1}$ Chung Hwan Kim, ${ }^{3}$ Inhwan Hwang ${ }^{2}$ \\ and Jongsik Chun ${ }^{4}$
}

\author{
1,2 Department of \\ Microbiology ${ }^{1}$ and \\ Department of Molecular \\ Biology22, Gyeongsang \\ National University, \\ Chinju 660-701, Republic \\ of Korea \\ 3 Department of Clinical \\ Pathology, Masan \\ College, Masan 630-729, \\ Republic of Korea \\ 4 Korean Collection for \\ Type Cultures, Korea \\ Research Institute of \\ Bioscience \& \\ Biotechnology, Taejon \\ 305-600, Republic of \\ Korea
}

\author{
Author for correspondence: Young Ryun Chung. Tel: +82 591751 5945. Fax: +82 5917590187. \\ e-mail:yrchung@nongae.gsnu.ac.kr
}

Keywords: Paenibacillus koreensis, iturin-like antifungal

\section{INTRODUCTION}

The genus Paenibacillus was created to harbour a phylogenetically coherent group of aerobic or facultatively anaerobic endospore-forming bacilli on the basis of 16S rRNA analysis (Ash et al., 1993; Shida et al., 1997a). The genus currently contains 24 species and is phenotypically related to other genera belonging to the family Bacillaceae. A highly specific primer, PAEN515F, was recently designed for the detection of 16S rRNA gene of the genus Paenibacillus and used to produce a $0.8 \mathrm{~kb}$ PCR amplicon in preparations from the 18 paenibacilli by amplifications in conjunction with primer 1377R (Shida et al., 1997a). The method proved to be useful for identifying and differentiating Paenibacillus species from other members of the family Bacillaceae. More recently, Paenibacillus campinasensis, an alkaliphilic species, Paenibacillus dendritiformis, forming a distinctive growth pattern, and Paenibacillus lentimorbus and Paenibacillus popilliae, which cause milky disease in insects, have been introduced as new members of the genus

Abbreviation: TSA, tryptic soy agar.

The GenBank accession number for the $16 \mathrm{~S}$ rDNA sequence of strain $\mathrm{YC} 300^{\top}$ is AF130254.
(Pettersson et al., 1999; Tcherpakov et al., 1999; Yoon et al., 1998).

Some members of the genus, including Paenibacillus polymyxa and Paenibacillus thiaminolyticus, are known to produce antibacterial compounds such as polymyxin, octopytin and baciphelacin (Slepecky \& Hemphill, 1991). However, no antifungal compound has been reported to be produced by Paenibacillus species so far, although iturins, cyclic peptide antifungals, are produced by several isolates of Bacillus subtilis (Lancini \& Lorenzetti, 1993). In addition to the production of antibiotics, several species of Paenibacillus are also known to excrete a wide variety of enzymes that degrade natural biopolymers, such as chondroitin, curdlan and chitin (Claus \& Berkeley, 1986; Kanzawa et al., 1995; Nakamura, 1987). A chitinolytic bacterial strain, designated $\mathrm{YC} 300^{\mathrm{T}}$, was isolated from a compost sample collected from Chinju, Republic of Korea, in the process of screening biological control agents for Rhizoctonia solani, a plantpathogenic fungus. The strain also showed strong antifungal activity against Fusarium oxysporum, Colletotrichum lagenarium, Sclerotinia sclerotiorum and Botrytis cinerea (Chung, 1997). The taxonomic status of strain $\mathrm{YC} 300^{\mathrm{T}}$ was investigated using a combination of phenotypic, chemical and molecular 
systematic methods. On the basis of polyphasic evidence, we propose that strain $\mathrm{YC} 300^{\mathrm{T}}$ be classified in the genus Paenibacillus as Paenibacillus koreensis sp. nov.

\section{METHODS}

Bacterial strain. Strain $\mathrm{YC} 300^{\mathrm{T}}$ was isolated from a compost sample prepared with rice husk and fishery industrial wastes collected from Chinju, Republic of Korea, using the standard dilution agar plating method. Aliquots of serially diluted soil suspension were inoculated onto minimal salt agar medium containing $0.5 \mathrm{~g} \mathrm{MgSO}_{4} .7 \mathrm{H}_{2} \mathrm{O}, 0.7 \mathrm{~g} \mathrm{~K}_{2} \mathrm{HPO}_{4}$, $0.3 \mathrm{~g} \mathrm{KH}_{2} \mathrm{PO}_{4}, 0.01 \mathrm{~g} \mathrm{FeSO}_{4} . \mathrm{H}_{2} \mathrm{O}, 0.001 \mathrm{~g} \mathrm{ZnSO}_{4}$ and $0.001 \mathrm{~g} \mathrm{MnCl}_{2}$ per litre distilled water supplemented with $0.2 \%(\mathrm{w} / \mathrm{v})$ colloidal chitin prepared from crab shell chitin (Sigma) as sole carbon and nitrogen source (Chung et al., 1989). Bacterial colonies were picked up $3 \mathrm{~d}$ following incubation at $28{ }^{\circ} \mathrm{C}$ and their inhibitory activities against Rhizoctonia solani and Fusarium oxysporum were determined by paired bioassay on potato dextrose agar (Difco) and $0 \cdot 1 \times$ tryptic soy agar (TSA; Difco) plates. An isolate, designated $\mathrm{YC} 00^{\mathrm{T}}$, showing substantial inhibition of mycelial growth of fungi was selected and studied further. The strain was maintained on TSA at $4{ }^{\circ} \mathrm{C}$.

Morphological and physiological characteristics. The cells were grown at $28^{\circ} \mathrm{C}$ using a fermenter (51; Korea Fermentation; aeration: $31 \mathrm{~min}^{-1}$, 300 r.p.m.) containing soybean meal media (SM; 2 g yeast extract, $1 \mathrm{~g}$ beef extract, $20 \mathrm{~g}$ soluble starch, $25 \mathrm{~g}$ soybean meal, $5 \mathrm{~g}$ dextrose, $0.5 \mathrm{~g}$ $\mathrm{K}_{2} \mathrm{HPO}_{4}, 2 \mathrm{~g} \mathrm{NaCl}, 0 \cdot 5 \mathrm{~g} \mathrm{MgSO}_{4} \cdot 7 \mathrm{H}_{2} \mathrm{O}, 6 \mathrm{~g} \mathrm{CaCO}_{3}$ per litre distilled water) and sampled after $4,12,24$ and $48 \mathrm{~h}$. The morphological properties were examined by light microscopy after Gram staining. Vegetative cells and spores were fixed with glutaraldehyde/osmium and after sectioning and staining the specimens were observed by using a transmission electron microscope (Hitachi model H-600). The methods described by Smibert \& Krieg (1981) were used for the following physiological tests: oxidase, catalase, indole production, Voges-Proskauer reaction, nitrate reduction, motility and hydrolysis of casein, starch, chitin and chitosan. Carbohydrate utilization and other tests described below were performed with GNI and BAC cards according to the instructions of the VITEK system (AMS 60; bioMérieux). Growth in the presence of $7 \%(\mathrm{w} / \mathrm{v}) \mathrm{NaCl}$ and $0.001 \%$ lysozyme, and the temperature range for growth were determined using $0 \cdot 1 \times$ TSA as basal medium.

Chemotaxonomy. The biomass for cellular fatty acid analysis was prepared from a 1-d-old culture grown on a TSA plate at $28^{\circ} \mathrm{C}$. Fatty acid methyl esters were prepared using the method described in the manual of the MIDI Microbial Identification System (Hewlett Packard). The resultant esters were separated using a gas chromatograph (model 5890; Hewlett Packard) fitted with a phenylmethyl silicone fused silica capillary column $(25 \mathrm{~m} \times 0.2 \mathrm{~mm}$; Hewlett Packard).

DNA base composition. The $\mathrm{G}+\mathrm{C}$ content of the DNA was determined from the midpoint value of the thermal denaturation profile using a spectrophotometer (Ultrospec 2000; Pharmacia Biotech) equipped with programmable peltier temperature control unit according to the equation of Marmur \& Doty (1962) as modified by De Lay (1970).

16S rDNA sequencing. 16S rDNA was enzymically amplified using two oligonucleotide primers as described previously (Chung et al., 1999). The sequences of the two primers are 5'-
TATGGATCCTTCTACGGAGAGTTTGATCC-3' and 5'-T ATGGATCCCACCTTCCGGTACGGCTACC-3' (BamHI sites are indicated by underlining). The temperatures for denaturation, annealing and extension were 94,55 and $72{ }^{\circ} \mathrm{C}$, respectively. The PCR products were digested with Bam HI and cloned into linearized pBluescript II SK $(+)$ vector. Overlapping subclones were generated by exonuclease III digestion of the insert DNA. The nucleotide sequences of these clones were sequenced using an automatic sequencer (ABI), according to the manufacturer's protocol.

Phylogenetic analysis. The resultant $16 \mathrm{~S}$ rDNA sequence of strain $\mathrm{YC} 300^{\mathrm{T}}$ was manually aligned with representative sequences of paenibacilli and related taxa obtained from the Ribosomal Database Project (Maidak et al., 1997) and GenBank databases, using known 16S rRNA secondary structure information. Phylogenetic trees were inferred by using three treeing algorithms, namely the Fitch-Margoliash (Fitch \& Margoliash, 1967), maximum-parsimony (Fitch, 1972) and neighbour-joining (Saitou \& Nei, 1987) methods. Evolutionary distance matrices for the neighbour-joining and Fitch-Margoliash methods were generated according to the model of Jukes \& Cantor (1969). The trees were rooted using Alicyclobacillus acidocaldarius (accession no. X60742) and Brevibacillus laterosporus (D16271) as outgroups. The PHYLIP package (Felsenstein, 1993) was used for all analyses. The resultant unrooted tree topology was evaluated in bootstrap analyses (Felsenstein, 1985) of the neighbourjoining method based on 1000 resamplings.

Paenibacillus specific PCR. The Paenibacillus-specific primer PAEN515F (5'-GCTCGGAGAGTGACGGTACCTGAGA-3') and universal primer 1377R (5'-GGCATGCTGATCCGCGATTACTAGC-3') were applied to isolate

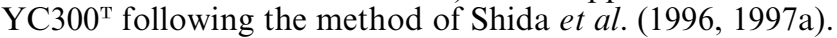
The universal forward and reverse primers, $27 \mathrm{FC}$ and 1377R, were also used for PCR amplification.

\section{RESULTS}

\section{Morphological and physiological characteristics}

Cells grown vegetatively were Gram-positive and rodshaped, measuring $0 \cdot 5-0.9 \times 2 \cdot 3-4.5 \mu \mathrm{m}$. Ellipsoidal endospores were produced in swollen sporangia in a fermenter at $28^{\circ} \mathrm{C}$ (Fig. 1). During the early and

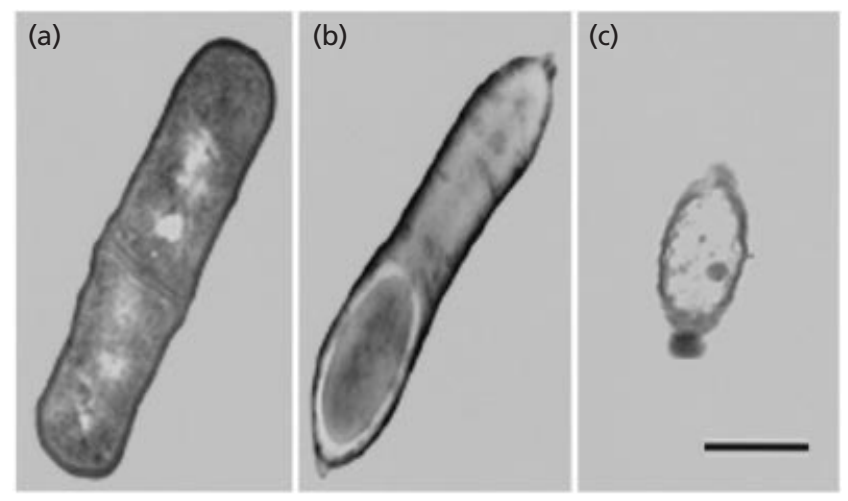

Fig. 1. Electron micrograph of vegetative cell (a), endospore in swollen sporangia (b) and endospore (c) of strain $\mathrm{YC}^{\circ} \mathrm{O}^{\top}$. Bar, $1 \mu \mathrm{m}$. 


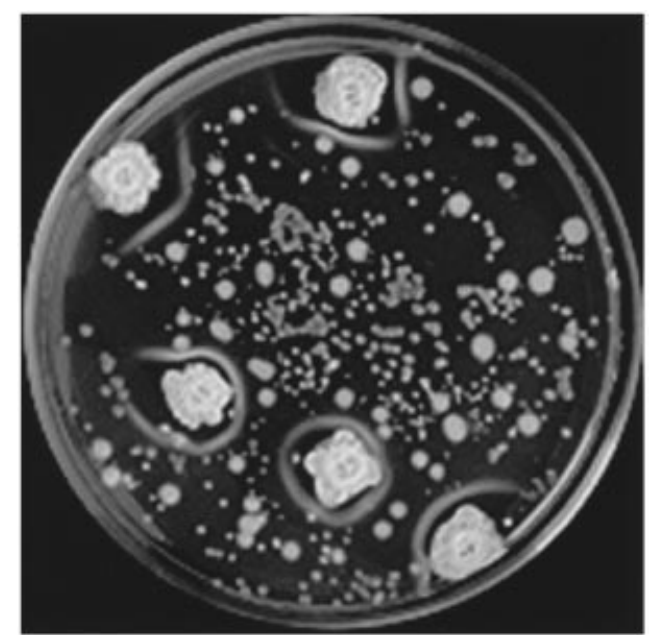

Fig. 2. Various colony morphologies of strain $\mathrm{YC} 300^{\top}$. The organism was grown on TSA at $28^{\circ} \mathrm{C}$ for $10 \mathrm{~d}$.

Table 1. Acid production from carbohydrates as sole carbon source by strain $\mathrm{YC} 300^{\top}$

,+- , positive or negative for carbohydrate

fermentation; $(+)$, positive for carbohydrate oxidation.

\begin{tabular}{|lc|}
\hline Carbohydrate & Reaction \\
\hline$N$-Acetyl-D-glucosamine & + \\
Amygdalin & - \\
Amylopectin & + \\
L-Arabinose & + \\
Adonitol & - \\
Arabitol & + \\
D-Galactose & + \\
D-Glucose & $+(+)$ \\
Inositol & + \\
Inulin & - \\
Lactose & $+(+)$ \\
Maltose & $+(+)$ \\
Mannitol & $+(+)$ \\
Palatinose & + \\
D-Raffinose & + \\
L-Rhamnose & - \\
D-Ribose & - \\
Salicin & - \\
Sorbitol & + \\
Sucrose & + \\
Tagatose & - \\
D-Trehalose & + \\
D-Xylose & $-(+)$ \\
\hline
\end{tabular}

exponential growth stages under well aerated conditions, cells were Gram-positive, but with the onset of spore formation, the cells became Gram-negative. The cells were motile by peritrichous flagella. Strain $\mathrm{YC} 300^{\mathrm{T}}$ formed three types of colonies on $0 \cdot 1 \times \mathrm{TSA}$ : (i) circular, flat, smooth and opaque; (ii) circular, convex, glistening and translucent; and (iii) circular or irregular, wrinkled hollow and opaque (Fig. 2). The first type was mainly developed. The strain was facultatively anaerobic and grew at $10-50{ }^{\circ} \mathrm{C}$ with an optimum growth temperature of $38-40{ }^{\circ} \mathrm{C}$. This strain grew in the presence of $0.001 \%$ lysozyme, but not in the presence of $7 \% \mathrm{NaCl}$. Oxidase, catalase, arginine dihydrolase and ornithine decarboxylase activities were observed, but not urease or lysine decarboxylase activities. Casein, chitin, chitosan, aesculin and starch were hydrolysed. Sodium acetate and malonate were utilized, but acetamide and citrate were not. Nitrate was reduced and tests for indole production and Voges-Proskauer reaction were negative. Reactions for the oxidation and fermentation of carbohydrates as sole carbon sources are shown in Table 1. Strain $\mathrm{YC} 00^{\mathrm{T}}$ inhibited growth of several plant and human fungal pathogens, such as Rhizoctonia solani, Fusarium oxysporum, Botrytis cinerea, Sclerotinia sclerotiorum, Colletotrichum lagenarium, Magnaporthe grisea, Botryosphaeria dothidea, Candida albicans and Trichophyton mentagrophyte, by producing iturin-like antifungal compounds. The active substance is composed of seven amino acids (Glu, Tyr, Ser, Pro, Asp1, Asp2, Asp3) and one $\beta$-amino acid, typical components of the iturins (S. S. Moon, personal communication).

\section{Chemotaxonomy}

The predominant fatty acids in whole-cell methanolysates of strain $\mathrm{YC} 00^{\mathrm{T}}$ were anteiso-15:0 $(51 \cdot 1 \%)$, $16: 0(28 \cdot 3 \%)$ and iso-16:0 (20.6\%). The $\mathrm{G}+\mathrm{C}$ content of the DNA was $54 \mathrm{~mol} \%$.

\section{S rDNA analysis}

The almost complete sequence of the 16S rDNA of strain $\mathrm{YC} 00^{\mathrm{T}}$ was determined $(1536 \mathrm{bp})$. The preliminary phylogenetic analysis based on a large data set consistently placed strain $\mathrm{YC}_{300^{\mathrm{T}}}$ in a clade corresponding to the genus Paenibacillus (data not shown). The detailed evolutionary relationships between strain $\mathrm{YC} 300^{\mathrm{T}}$ and all of the validly described Paenibacillus species were examined using the neighbour-joining method (Fig. 3). Strain YC300 ${ }^{\mathrm{T}}$ was recovered in a monophyletic clade containing the type strains of Paenibacillus alginolyticus, Paenibacillus chondroitinus, Paenibacillus larvae and Paenibacillus validus, the relationship supported by a high bootstrap value of $96 \%$. The reconstruction of this clade was also confirmed in the Fitch-Margoliash and maximum-parsimony analyses. Furthermore, the isolate formed a monophyletic subclade with $P$. validus with $86 \%$ bootstrap support. Comparative analysis of 16S rDNA primary structure indicated that strain $\mathrm{YC} 300^{\mathrm{T}}$ is distantly related to all of the validly described Paenibacillus species as pairwise sequence 


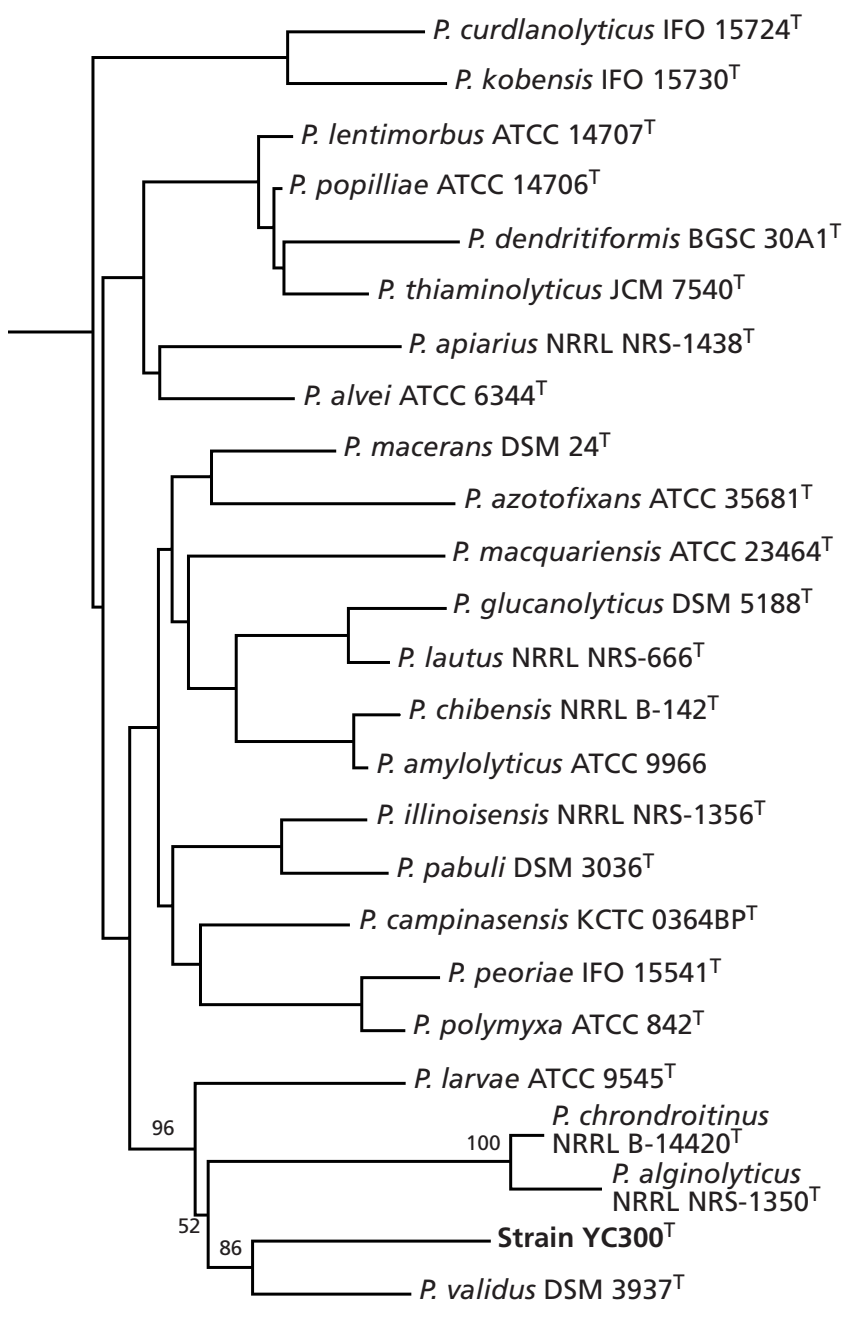

$0 \cdot 1$

Fig. 3. A rooted neighbour-joining tree based on 1396 unambiguously aligned nucleotide positions, including positions 45-70, 98-1133 and 1141-1431 (E. coli numbering; Brosius et al., 1981). The numbers at the nodes exhibit the levels of bootstrap support based on neighbour-joining analyses of 1000 resampled data sets. The scale bar represents $0 \cdot 1 \mathrm{nt}$ substitutions per position.

similarity values range from $94 \cdot 8$ (P. validus) to $89.8 \%$ (P. dendritiformis).

\section{PCR amplifications and molecular systematics}

PCR amplification using primers PAEN515F and $1377 \mathrm{R}$ produced a $0.9 \mathrm{~kb} \mathrm{PCR}$ fragment in the preparation of strain $\mathrm{YC} 300^{\mathrm{T}}$. A $1 \cdot 3 \mathrm{~kb}$ fragment was also amplified in the strain tested with bacterial universal primers $27 \mathrm{FC}$ and $1377 \mathrm{R}$.

\section{DISCUSSION}

It is evident from the results of Paenibacillus-specific PCR amplification and comprehensive phylogenetic analyses based on $16 \mathrm{~S}$ rDNA sequence data that strain YC300 ${ }^{\mathrm{T}}$ belongs to the genus Paenibacillus. Shida et al. (1997a) reported that a $0.8 \mathrm{~kb}$ fragment was produced from paenibacilli using the same primers under the reaction conditions used in the present study. Careful examination of $16 \mathrm{~S}$ rDNA sequences of all Paenibacillus type strains clearly indicated that the primer pair set should yield a fragment in the size range 895 (Paenibacillus apiarius) to $907 \mathrm{bp} \mathrm{(P.}$ dendritiformis). Therefore, the size of the Paenibacillusspecific PCR amplicon should be 0.9 instead of $0.8 \mathrm{~kb}$. The genetic uniqueness of our isolate among the paenibacilli was evident, as none of the validly described species showed $95 \%$ or greater $16 \mathrm{~S}$ rDNA sequence similarity, a level of similarity far less than the borderline for defining bacterial genomic species, i.e. $97 \%$, proposed by Stackebrandt \& Goebel (1994).

The chemotaxonomic data, i.e. $\mathrm{G}+\mathrm{C}$ content of DNA $(54 \mathrm{~mol} \%)$ and the anteiso-15:0 fatty acid as the major cellular fatty acid $(51 \cdot 1 \%)$, also fall within the ranges exhibited by Paenibacillus species (Shida et al., 1997a, b; Yoon et al., 1998). In a comparison of phenotypic characteristics of strain $\mathrm{YC} 300^{\mathrm{T}}$ with those of phylogenetically closely related Paenibacillus species, $P$. validus, $P$. chondroitinus and $P$. alginolyticus, strain $\mathrm{YC} 00^{\mathrm{T}}$ exhibited several differential properties. Strain $\mathrm{YC}_{300^{\mathrm{T}}}$ grew anaerobically and had oxidase activity in opposition to those related species. Xylose was not fermented by the isolate. The Gram reaction of $\mathrm{YC} 300^{\mathrm{T}}$ was variable, depending on the growth stage and culture medium, a phenomenon often observed in Bacillus species (Claus \& Berkeley, 1986). The appearance of colonies was variable depending on culture media and three different colony types were developed on TSA. Each colony produced these various colony types in many repeated experiments. We could not find the culture conditions necessary to induce colonial variation of strain $\mathrm{YC} 00^{\mathrm{T}}$. Such variations in colony morphology can also be observed in many Bacillus species (Claus \& Berkeley, 1986). Like other Paenibacillus species, including Paenibacillus alvei, Paenibacillus macerans, Paenibacillus polymyxa and P. thiaminolyticus, strain $\mathrm{YC} 300^{\mathrm{T}}$ has the ability to degrade many natural biopolymers, such as chitin (Nielson \& Sorensen, 1997; Shida et al., 1997a). The isolate has been used as the biological control agent of soil-borne pathogens because of its ability to degrade chitin, a major component of the fungal cell wall (Singh et al., 1999). $\mathrm{YC} 300^{\mathrm{T}}$ produces iturin-like antifungal agents, the structures of which were elucidated by a series of chromatographic and spectroscopic analyses. Some Bacillus and Paenibacillus species are known to produce antifungal and antibacterial substances, such as bacillomycin and polymyxin (Slepecky \& Hemphill, 1991). However, no production of an antifungal by Paenibacillus species has been reported to date. To our knowledge, this is the first report of the production of an iturin-like antifungal by Paenibacillus species.

On the basis of polyphasic evidence, we propose that 
strain $\mathrm{YC} 300^{\mathrm{T}}$ be assigned in the genus Paenibacillus as Paenibacillus koreensis sp. nov.

\section{Description of Paenibacillus koreensis sp. nov.}

Paenibacillus koreensis (ko.re.en'sis, M.L. masc. adj. koreensis indicating Korea, the geographical origin of isolation).

Cells are rod-shaped, measuring 0.5-0.9 $\times 2 \cdot 3-4.5 \mu \mathrm{m}$ and motile by peritrichous flagella. Ellipsoidal spores are formed in swollen sporangia. Three types of colonies are formed when grown on $0 \cdot 1 \times$ TSA: circular, flat, smooth and opaque; circular, convex, glistening and translucent; and circular or irregular, wrinkled hollow and opaque. Facultatively anaerobic, growing at $10-50{ }^{\circ} \mathrm{C}$ with an optimum growth temperature of $38-40^{\circ} \mathrm{C}$. Growth occurs in the presence of $0.001 \%$ lysozyme, but not in the presence of $7 \% \mathrm{NaCl}$. Positive for oxidase, catalase, arginine dihydrolase, ornithine decarboxylase and nitrate reduction. Negative for urease, lysine decarboxylase, indole production and Voges-Proskauer reaction. Casein, chitin, chitosan, aesculin and starch are hydrolysed. Utilizes sodium acetate and malonate as sole carbon sources, but not acetamide and citrate. Acid is produced from glucose, lactose, maltose, mannitol and xylose oxidatively, and fermentatively from arabinose, arabitol, amylopectin, $N$-acetyl-D-glucosamine, galactose, glucose, inositol, lactose, maltose, mannitol, palatinose, raffinose, sorbitol and sucrose. Carbohydrates not utilized by the species are shown in Table 1. The major fatty acid is anteiso-15:0. The $\mathrm{G}+\mathrm{C}$ content is $54 \mathrm{~mol} \%$. A $16 \mathrm{~S} \mathrm{rDNA}$ fragment $(0.9 \mathrm{~kb})$ is amplified by PCR with primers PAEN515F and 1377R. Inhibits the growth of fungi by producing an iturin-like antifungal compound. The type strain is Paenibacillus koreensis $\mathrm{YC} 300^{\mathrm{T}}$ and has been deposited in the Korean Collection for Type Cultures and the Korean Culture Center of Microorganisms under the accession numbers KCTC $2393^{\mathrm{T}}$ and KCCM $40903^{\mathrm{T}}$, respectively.

\section{ACKNOWLEDGEMENTS}

This work was supported by a grant No. KOSEF 96-04-0201-01-3 from the Korea Science and Engineering Foundation (KOSEF).

\section{REFERENCES}

Ash, C., Priest, F. G. \& Collins, M. D. (1993). Molecular identification of rRNA group 3 bacilli (Ash, Farrow, Wallbanks and Collins) using a PCR probe test. Proposal for the creation of a new genus Paenibacillus. Antonie Leeuwenhoek 64, 253-260.

Brosius, J., Dull, T. J., Sleeter, D. D. \& Noller, H. F. (1981). Gene organization and primary structure of a ribosomal RNA operon from Escherichia coli. J Mol Biol 148, 107-127.

Chung, M. H. (1997). Biological control of Rhizoctonia dampingoff of radish by antagonistic bacteria with chitinolytic activity in commercial bed soils. MSc thesis, Gyeongsang National University, Chinju, Korea (in Korean).
Chung, Y. R., Ohh, S. H. \& Chung, H. S. (1989). Antagonistic activity of Streptomyces species against Fusarium solani causing ginseng root rot. Korean J Microbiol 27, 56-62.

Chung, Y. R., Sung, K. C., Mo, H. K., Son, D. Y., Nam, J. S., Chun, J. \& Bae, K. S. (1999). Kitasatospora cheerisanensis sp. nov., a new species of the genus Kitasatospora that produces an antifungal agent. Int J Syst Bacteriol 49, 753-758.

Claus, D. \& Berkeley, R. C. W. (1986). Genus Bacillus Cohn 1872. In Bergey's Manual of Systematic Bacteriology, vol. 2, pp. 1105-1140. Edited by P. H. A. Sneath, N. S. Mair, M. E. Sharpe \& J. G. Holt. Baltimore: Williams \& Wilkins.

De Ley, J. (1970). Re-examination of the association between melting point, buoyant density, and chemical base composition of deoxyribonucleic acid. J Bacteriol 101, 738-754.

Felsenstein, J. (1985). Confidence limits on phylogenies: an approach using the bootstrap. Evolution 39, 783-791.

Felsenstein, J. (1993). PHYLIP (Phylogeny Inference Package) version 3.5.1. Seattle: Department of Genetics, University of Washington.

Fitch, W. M. \& Margoliash, E. (1967). Construction of phylogenetic trees. Science 155, 279-284.

Fitch, W. M. (1972). Toward defining the course of evolution: minimum change for a specific tree topology. Syst Zool 20, 406-416.

Jukes, T. H. \& Cantor, C. R. (1969). Evolution of protein molecules. In Mammalian Protein Metabolism, pp. 21-132. Edited by H. N. Munro. New York: Academic Press.

Kanzawa, Y., Harada, A., Takeuchi, A., Yokota, A. \& Harada, T. (1995). Bacillus curdlanolyticus sp. nov. and Bacillus kobensis sp. nov., which hydrolyze resistant curdlan. Int J Syst Bacteriol 45, 515-521.

Lancini, G. \& Lorenzetti, R. (1993). Biotechnology of Antibiotics and Other Bioactive Microbial Metabolites. New York: Plenum.

Maidak, B. L., Olsen, G. J., Larsen, N., Overbeek, R., McCaughey, M. J. \& Woese, C. R. (1997). The RDP (Ribosomal Database Project). Nucleic Acids Res 25, 109-111.

Marmur, J. \& Doty, P. (1962). Determination of the base composition of deoxyribonucleic acid from its thermal denaturation temperature. J Mol Biol 5, 109-118.

Nakamura, L. K. (1987). Bacillus alginolyticus sp. nov. and Bacillus chondroitinus sp. nov., two alginate-degrading species. Int J Syst Bacteriol 37, 284-286.

Nielson, P. \& Sorensen, J. (1997). Multi-target and mediumindependent fungal antagonism by hydrolytic enzymes in Paenibacillus polymyxa and Bacillus pumilus strains from barley rhizosphere. FEMS Microb Ecol 22, 183-192.

Pettersson, B., Rippere, K. E., Yousten, A. A. \& Priest, F. G. (1999). Transfer of Bacillus lentimorbus and Bacillus popilliae to the genus Paenibacillus with emended description of Paenibacillus lentimorbus comb. nov. and Paenibacillus popilliae comb. nov. Int $J$ Syst Bacteriol 49, 531-540.

Saitou, N. \& Nei, M. (1987). The neighbor-joining method: a new method for reconstructing phylogenetic trees. Mol Biol Evol 4, 406-425.

Shida, O., Takagi, H., Kadowaki, K. \& Komagata, K. (1996). Proposal for two new genera, Brevibacillus gen. nov. and Aneurinibacillus gen. nov. Int J Syst Bacteriol 46, 939-946.

Shida, O., Takagi, H., Kadowaki, K., Nakamura, L. K. \& Komagata, K. (1997a). Transfer of Bacillus alginolyticus, Bacillus chondroitinus, Bacillus curdlanolyticus, Bacillus glucanolyticus, Bacillus kobensis, and Bacillus thiaminolyticus to the genus 
Paenibacillus and emended description of the genus Paenibacillus. Int J Syst Bacteriol 47, 289-298.

Shida, O., Takagi, H., Kadowaki, K., Nakamura, L. K. \& Komagata, K. (1997b). Emended description of Paenibacillus amylolyticus and description of Paenibacillus illinoisensis sp. nov. and Paenibacillus chibensis sp. nov. Int J Syst Bacteriol 47, 299-306.

Singh, P. P., Shin, Y. C., Park, C. S. \& Chung, Y. R. (1999). Biological control of Fusarium wilt of cucumber by chitinolytic bacteria. Phytopathology 89, 92-99.

Slepecky, R. A. \& Hemphill, H. E. (1991). The genus Bacillus nonmedical. In The Prokaryotes, pp. 1663-1696. Edited by A. Balows, H. G. Trüper, M. Dworkin, W. Harder \& K. H. Schleifer. New York: Springer.

Smibert, R. M. \& Krieg, N. R. (1981). General characterization. In Manual of Methods for General Bacteriology, pp. 409-433.
Edited by P. Gerhardt, R. G. E. Murray, R. N. Costilow, E. W. Nester, W. A. Wood, N. R. Krieg \& G. B. Phillips. Washington, DC: American Society for Microbiology.

Stackebrandt, E. \& Goebel, B. M. (1994). Taxonomic note: a place for DNA-DNA reassociation and 16S rRNA sequence analysis in the present species definition in bacteriology. Int $J$ Syst Bacteriol 44, 846-849.

Tcherpakov, M., Ben-Jacob, E. \& Gutnick, D. L. (1999). Paenibacillus dendritiformis sp. nov., proposal for a new patternforming species and its localization within a phylogenetic cluster. Int J Syst Bacteriol 49, 239-246.

Yoon, J. H., Yim, D. K., Lee, J. S., Shin, K. S., Sato, H. H., Lee, S. T., Park, Y. K. \& Park, Y. H. (1998). Paenibacillus campinasensis sp. nov., a cyclodextrin-producing bacterium isolated in Brazil. Int J Syst Bacteriol 48, 833-837. 